\title{
Problems and Suggestions on the Securitization of China's Financing Leasing Assets
}

\author{
Lijuan Chang, Nan $\mathrm{Wu}^{*}$ \\ Shaanxi Normal University International Business School \\ Xi'an, Shaanxi \\ Email: wunan_xa@163.com
}

\begin{abstract}
Asset-backed Securities is the future of financial market. In this regard, financing lease industry deploys the best characteristics for securitization which will also facilitate the development of this industry. Therefore, we conclude the workflow of financial lease asset securitization and analyze the benefits of financial lease asset securitization for markets in this work. Furthermore, we give suggestions in terms of legal policies and credit risks for better development of financial lease asset securitization.
\end{abstract}

Keywords-Financial leasing; Asset-backed Securities; Financial market; Suggestions

\section{INTRODUCTION}

Asset-backed Securities (ABS) is the structured financial activities that repacking and enhancing credits of some assets, and then issuing negotiable securities in the financial market base on the further cash flow of the assets or asset portfolios [1].Those assets have predictable and stable cash flows in future, although they lack immediate liquidity. ABS is a kind of innovative and flexible financing methods rendering it important and competitive in the real economy. More specifically, ABS can effectively activate the asset inventory, adjust the debt structure and to some extent promote the reputation of enterprises. As to the shortage of financial leasing funds and unbalanced debts between short-term and long-term in the financing industry, securitizing the financial leasing claims, namely financing lease asset securitization could be feasible method in future. Financing lease asset securitization has this own advantages: reducing the financing threshold of enterprises; lowering financing costs; segregating bankruptcy risks between securitized assets and financial leasing companies; spreading the credit line into numerous institutional investors to reduce risks. Furthermore, the financial leasing asset securitization has the characteristics of direct financing, which is easier for the financial leasing company to convert the leased assets into negotiable securities in the financial market based on stable cash flows through a certain transaction structure arrangement. As the development and maturity of the securities market, we believe the financial leasing asset securitization can play a pivotal role in the real economy.

\section{OVERVIEW OF THE FINANCIAL LEASING ASSETS SECURITIZATION}

\section{A. The financial leasing}

The financing leasing is one of important financing methods. It serves the situation like that when a company lacks funds to buy large equipments, it can request equipments from a financing leasing company. As a third-party financing leasing company purchases the specified leasing equipments from the supplier, and then leases them to the company. The company pays rents to the financing leasing company according to provisions of the financial leasing agreement. During the lease period, the ownership of the leased property belongs to the lessor while the lessee only has the right to use.

The financial leasing industry is a capital-intensive industry The prerequisite of this industry is having a solid financial strength. Except this, the growth of financial leasing companies depends not only on their business development capabilities, but also on the size of their financing capacity and the levels of capital management. As an important financing method, financial leasing has solved the problems that many small and medium-sized enterprises (SMEs) can not afford the equipments they need. For enterprises who need financing lease equipment, financial leasing can not only let them to select equipments for effective operation and increase fund allocation efficiency, but also reduce equipment purchase risks. On the other hand, as a financial leasing company, during this activity, it has high rate of return and controllable default risks.

With the background of economic restructuring in China in recent years, Asset-backed Securities has become a hot topic of attention because it can revitalize long-term assets and improve the efficiency of capital allocation. However, Asset-backed Securities requires high demands of basic assets with predictable steady cash flows. In this regard, the financial leasing industry is the best candidate for Asset-backed Securities, indicating that the implementation of Asset-backed Securities in the financial leasing industry is overwhelming. The financing lease asset securitization can expand the financing channels of leasing companies, break the financing bottleneck, solve the financing needs of the financing leasing companies, reduce the financing cost risks, and increase the reputation of companies [2]. Therefore, the government should encourage financial leasing companies to vigorously develop 
securitization businesses and increase their ability to raise funds for better serving the real economy.

\section{B. Financial leasing asset securitization}

Financial leasing asset securitization refers to the fact that financial leasing companies, as promoters, use their own leasing claims that can generate large-scale stable cash flows as their basic assets and transfer them to SPV (special purpose vehicle).SPV issues securities in the financial market based on those basic assets with stable cash flows. The procedure of financial leasing asset securitization is complicated and involves many entities. Generally, the entities consist of promoters, SPV, investors, lessees, rating agencies, and law firms.

The workflow of the financial leasing asset securitization is as follows: first, financial leasing companies pack all kinds of the same or similar lease claims with low liquidity together to make one asset package; second, financial leasing companies sell the asset package to SPV to obtain funds for sales of lease claims. SPV is crucial for Asset-backed Securities because it can achieve bankruptcy segregation between sponsors and basic assets; third, SPV requires the third-party service agencies to upgrade the credit, rate the ranking and guarantee the securities which are prepared to be issued; fourth, SPV issues Asset-backed Securities through underwriters by using their claims as collateral. Intermediary agencies in the secondary market sell bonds to investors and get funds from investors.

The reasons that the financial leasing asset securitization can convert low liquidity of rented bonds with stable funds return period into negotiable securities in the financial market are three principles, namely asset re-organization, risk segregation, and credit enhancement. Those principles have an important role in risk prevention during the financial leasing asset securitization. Asset re-organization is the process that owners of lease claims pack their same or similar assets to a large package through matching risks and returns of those claims, which is able to reduce credit risks. Risk segregation is the process that segregates the risks of basic assets from the risks of the original rights holders. This step plays a crucial role in the success of the financial leasing asset securitization, while SPV is indispensable during this activity. If there is no bankruptcy segregation mechanism, the credits that are used as basic assets may become the bankrupt property of the original equity holders. Credit enhancement is to reduce information asymmetry, increase the credit rating of Asset-backed Securities through internal and external credit enhancement mechanisms, thus attracting investors and reducing financing costs.

\section{The significance of the development of financial leasing assets securitization}

For financial leasing companies, compared with the previous financing channels based on bank loans, Asset-backed Securities has its own characteristics and advantages. Financing leasing companies separate some lease claims that can be securitized from the company 'overall assets and sell them to SPV.As the basic conditions for the issuance of securities, those assets that can generate stable income in the future will be securitized. Because of uncertainty that the recovery of rental income in the future, we should make reasonable predictions of default risks and adopt various measures such as prioritization and guarantees to increase investors' trust and allow the market to develop soundly.

As a direct financing mode, securitization of financial leasing assets has positive significance in economic development. For a financial leasing company, because its main business is to purchase a large number of equipment and then sublet, a large amount of rental income can not be recovered in the short term, so it forms a variety of lease claims with future stable income rights. By packaging these lease claims into securitization, first, we can solve the financial dilemma of the company, alleviate the phenomenon of the mismatch of the long and short debts that financial leasing company use bank loans to make up for the funds of equipment and broaden the financing channels .Secondly, the securitization of financial leasing assets provides a low-cost financing method and increases the income for financial leasing companies, because securitization of financial leasing assets is a kind of securities issued under the guarantee of leasing claims. Through credit rating and enhancement, the conditions of securities issuance can be further improved, the costs of financial leasing companies can be reduced, and business development can be promoted. Thirdly, Asset-backed Securities can realize the rapid recovery of funds, enhance the liquidity of their own funds, improve the efficiency of asset allocation, and the company issue Asset-backed Securities publicly in the capital market, it can help the company enhance it's image. Finally, because Asset-backed Securities requires bankruptcy isolation, the basic assets of securitization are stripped out, the risk of operation of related basic assets is also transferred, and the assets are actually stripped from the balance sheet, this form of financing alleviates the leverage limits of financial leasing companies, optimizes financial statements and reduces the risk of default. At the same time, because the enterprise converts future income into the current income, so it avoids the risk of prepayment and credit risk which are the risk that financial leasing company needs to bear previously.

For investors, the income of the financing lease asset securitization is more stable, the financial leasing business break up the principal into parts which can repayment in installments, and the basic assets are the leasehold claims that can produce stable and sustained cash income, the repayment of investors is quick, the risk is relatively low. And in transaction structure design of leasing asset securitization, related project risk will be control appropriately. The securitization of financing lease assets adds new investment varieties to the investment market, broadens the options of 
investors' investment channels and the kind of investment, and meets the needs of different investors.

\section{PROBLEMS WITH THE SECURITIZATION OF FINANCIAL LEASE ASSETS}

The financial leasing industry has always faced the problem of a single financing channel and financial difficulties. Assetbacked Securities, an innovative financing tool, has opened up new financing channels for it [3].The application of this tool not only enables the financial leasing company to break through the leverage limit of the company, but also reduces the financing cost. Although many achievements have been made in the market of Asset-backed Securities, there are still many problems that need to be resolved to develop the financial leasing asset securities market better.

\section{A. Lack of relevant laws and policies}

\section{1) The tax policy is not sound enough}

The development of financial leasing asset securitization is affected by many factors, among which the policies is the core factors affecting its development [4].Although taxation is not a basic link in the securitization of financial leasing assets, it runs through all links and is a key and decisive factor in the success of financing. However, our country's fiscal policy lags behind [5]. On the one hand, the ambiguity and lag in China' taxation policy has hindered the development of financial leasing asset securitization. On the other hand, under the background of changing the business tax to added-value tax, assets are placed outside the balance sheet makes the basic assets out of the balance sheet of the financial leasing company. Due to the unclear tax status of SPVs, the issue of invoicing of value added tax and so on, these hindered the lessor' willingness to separate assets from the balance sheet to some extent. In order to make basic assets out of balance sheet, the financial leasing company must be select assets that do not involve value-added tax in the stock assets to carry out Asset-backed Securities business, which greatly narrows the range of assets that can be selected for pooling.

\section{2) Incomplete information disclosure system}

Information disclosure system plays an important role in the development of marketization. China's Asset-backed Securities market started late, but it has great potential in development. The development of securitization of financial leasing assets is still not enough mature, the relevant legal system is still not enough sound, and the information disclosure mechanism is still not perfect. The structure of financial leasing asset securitization transactions is complex, and it is difficult for investors to fully understand basic assets and other aspects of information. A standardized and transparent information disclosure system can allow investors to better understand related investment products, protect the interests of investors, and then increase market participation.

\section{B. Credit risk analysis of securitization of financial lease assets}

Credit risk refers to the default risk that the securitization participant fails to perform the contract for various reasons, thus causing certain losses to the investors. The reflection of credit risk in the process of securitization of financial leasing assets is mainly includes the default risks of lessor, lessees, and intermediary agencies. For example, the risk of the lessee failing to repay the loan on time or terminate lease contract ahead of schedule, the risk of the lessor's business or the authenticity of the underlying assets, the service quality and default risk in the follow-up service of the third-party service organization, etc. Regardless of the credit risk of any party involved, the impact on the entire process of securitization of financial lease assets is enormous, and it may lead to crisis. It is necessary to take certain credit risk management measures to identify, prevent and control these possible default risks.

\section{THE PROPOSALS TO FURTHER IMPROVE THE DEVELOPMENT OF CHINA'S FINANCIAL LEASING ASSET SECURITIZATION}

\section{A. In improving relevant laws and regulations.}

Countless experiences and practices show that the pace of innovation is much faster than the government's regulatory policies. Therefore, to promote the implementation of Assetbacked Securities in the financial leasing industry, a good legal environment is of utmost importance. The legal policies related to the securitization of financial leasing assets should be as simple and straightforward as possible to avoid inconsistencies between laws.

\section{1) In the aspect of taxation policy.}

Financial leasing business asset securitization products, as an innovative financial tool, have a complex business structure, and tax authorities should actively cooperate with the market to establish targeted taxation policies to establish the legal status of SPVs, and strengthen the implementation of relevant tax incentives in the securitization of financial leasing assets. We should spare no effort to promote the development of Assetbacked Securities businesses in financial leasing companies. In the choice of operation mode, the off-balance-sheet model will be more suitable for the development of China's financing leasing industry. It can realize real sales of basic assets, eliminate the uncertain risks of leasing claims, and achieve the target of isolating risks.

\section{2) In the aspect of information disclosure system.}

The financial crisis has made us realize the importance of formulating and implementing a good information disclosure system. At present, China's Asset-backed Securities market isn't mature. We should learn lessons from foreign and establish a specialized information disclosure mechanism, and disclose the different information according to the different products, and to ensure that investors can obtain timely, accurate and complete information, give information disclosure full role to play in marketization. The liquidity of bonds will promote the market development steadily and healthily and help investors make investment judgments, then allow more non-bank capital to enter the securitization market. In addition, 
high-quality information disclosure also helps the regulatory authorities to further track and manage the operation of the market.

On February 9, 2018, the Shanghai and Shenzhen Stock Exchange and the quotation and service system issued successively Guidelines of the Confirmation of Listing Conditions for Financial Lease Debt Asset-Backed Securities, and accompanying Guidelines for Disclosure of Information on Financial Lease Credit Asset-Backed Securities. The guidelines clarified the listing requirements for the securitization of credit lease assets and make the issuance and duration of financing lease ABS more standardized. It is believed that financial leasing asset securitization will serve the economic society better.

\section{B. Credit risk prevention mechanism for securitization of financial lease assets}

Asset-backed Securities has many advantages, it has played an important and positive role in the current economic society. However, we should look at this securitized product dialectically, neither blindly admiring it nor negating it altogether [6]. We should strengthen the supervision of risks and the repayment guarantees of basic assets in asset pools, establish a sound prevention mechanism for risk detection [7]. To be specific: to establish a multi-level professional credit enhancement agencies that will be restraint mutually in the process of financial leasing asset securitization; to strengthen the professionalism of rating agencies and the reliability of results to guarantee the stability of the future earnings of the basic assets; to realize an effective bankruptcy segregation mechanism to make the separation of the basic assets and the credit of the issuing entity, and wok in education for investors, meanwhile, guarantee the irrevocable of lease contract signed by lessees and financing leasing company.

\section{CONCLUSION}

Securitization of financial leasing assets is an important tool for solving financial bottlenecks and asset management difficulties of financial leasing companies. However, Assetbacked Securities is a "double-edged sword". Many problems remain to be solved in financial markets. Strengthening relevant laws and reducing credit risks will further help to promote the development of the securities market. We must find problems in practice constantly, and then put forward corresponding solutions and implementation as soon as possible, make good use of this innovative tool of asset securitization and let it better serve the real economy.

\section{REFERENCES}

[1] Changguo Liu. Research on the Design of Financial Lease Asset Securitization Products $[\mathrm{J}]$. Finance and Accounting Monthly, 2017(11):67-72. (In Chinese)

[2] Xiao Wang, Jia Li. Innovation and Supervision of Asset-backed Securities from the Perspective of Functional Perspective: Taking the New Normal of Economy as the Background [J]. Finance and Economics, 2016 (6):35-46. (In Chinese)

[3] Wei Wang, Jin Li. The taxation of Asset-backed Securities in financial leasing business under the background changing business tax to addedvalue tax [J]. Finance and Accounting,2017(17):45-47.(In Chinese)

[4] Yanfang Sun, Xiaoyue Wang, Yuhui Xiao. The Problems and Countermeasures in Applying Asset-backed Securities to Finance in PPP Projects [J]. Management Modernization, 2017,37(5). (In Chinese)

[5] Xiaofeng He, Xiufang Song. Game analysis in the Arrangement of Tax system of Asset-backed Securities [J]. Economic Science, 2001, Vol. 23(6):21-26. (In Chinese)

[6] Yan Xing. Problems and Countermeasures in the PPP project asset securitization in China [J]. Securities Market Herald,2017(5):40-44.(In Chinese)

[7] Shiqing Xie, Zhaoyuan Qin. Empirical Study on Cross-product Pricing of Asset-backed Securities [J]. Securities Market Herald, 2017(12):1323. (In Chinese) 